\title{
NO ENTREMEIO DA ANÁLISE DE DISCURSO E DA PSICANÁLISE: AS BORDAS DO REAL ${ }^{1}$
}

\author{
ALINE BEDIN JORDÃO \\ VERLI PETRI ${ }^{3}$
}

Programa de Pós-Graduação em Letras - Doutorado - Linha Língua, Sujeito e História Universidade Federal de Santa Maria (UFSM)

Av. Roraima, n. 1000 - Campus da UFSM. Centro de Artes e Letras - Prédio 16, Bairro Camobi. CEP 97105-900 - Santa Maria/RS, Brasil

alinebjoregmail.com ; verli.petri72@gmail.com

\begin{abstract}
Resumo. Considerando que há um real da língua, da história e do sujeito, busca-se uma aproximação da noção de "real" na interlocução da Análise de Discurso com a Psicanálise. Para tanto, concebe-se a língua afetada pelo inconsciente e pela história, subvertendo a ideia de unicidade; entende-se o sujeito dividido e evanescente. O real do sujeito remete ao seu saber nãosabido que não cessa de não se inscrever e aos efeitos da ideologia nas posições-sujeito. No que tange à história, infere-se que somente as suas versões são acessadas, pois apagamentos e silenciamentos operam e significam. O real da história está na dimensão do inenarrável. Em sua relação com o real, sujeitos, sentidos e história são constitutivamente dispersos, questão que demanda uma leitura de quem ocupa a posição de analista.
\end{abstract}

Palavras-chave: real; língua; sujeito; história.

\begin{abstract}
Considering that there is a real of language, history and subject, we seek an approximation of the notion of "real" in the interlocution of Discourse Analysis with Psychoanalysis. For that, the language affected by the unconscious and by history is conceived, subverting the idea of oneness; the subject is understood by divided and evanescent. The subject's real refers to his unknowable knowledge that never ceases to be inscribed and to the effects of ideology in the subject-positions. In terms of history, it is inferred that only its versions are accessed, since erasures and muting operate and signify. The real of history lies in the dimension of the unmentionable. Since in their relationship with the real, subjects, senses and history are constitutively dispersed, an issue that demands a reading of who occupies the position of analyst.
\end{abstract}

Keywords: real; language; subject; history.

\footnotetext{
${ }^{1}$ Este texto insere-se no escopo de nosso projeto de tese de doutorado, que traz reflexões sobre a ordem do real do corpo diante da construção da feminilidade, o que se situa no inominável e insuportável ao sujeito.

2 Doutoranda em Letras no Programa de Pós-Graduação em Letras da Universidade Federal de Santa Maria.

${ }^{3}$ Docente no Programa de Pós-Graduação em Letras da Universidade Federal de Santa Maria.
} 


\section{SITUANDO A PROPOSTA}

Partindo da afirmação de Pêcheux ([1981], 2016), no Colóquio "Materialidades Discursivas", de que há um real da língua, um real da história e um real do sujeito, buscase, no presente artigo, uma abertura dessa concepção, no intuito de promover uma aproximação com a noção de "real" nas formulações da Análise de Discurso (AD), perpassando as leituras oriundas da Psicanálise acerca desse conceito. Pretende-se discutir como esse tema circula e funciona nessas três dimensões: o real da língua, do sujeito e da história e suas implicações para os campos de pesquisa em questão.

Os estudiosos da Análise de Discurso trabalham com as materialidades linguístico-discursivas no entremeio das disciplinas com as quais dialogam. Assim, o real da língua, da história e do inconsciente referem-se ao impossível da Linguística, da História e da Psicanálise. Acerca dessa temática, Orlandi (2009, p. 19-20) propõe como premissas: “a) a língua tem sua própria ordem; b) a história tem seu real afetado pelo simbólico e c) o sujeito da linguagem é descentrado, pois [...] funciona pelo inconsciente e pela ideologia”. Para bordear essa questão, serão levados em conta estudos próprios às áreas da Psicanálise e da Análise de Discurso que contribuem para a discussão aqui proposta.

Lacan, em seus seminários, inúmeras vezes menciona e dialoga com os achados dos linguistas de sua época (como Saussure e Jakobson), ora utilizando-se e corroborando tais reflexões, ora discordando e desconstruindo-as. A AD, por sua vez, alimenta-se de conceitos psicanalíticos que lhe são caros para pensar a língua, o sujeito e o discurso, e acrescenta a compreensão ideológica e política pautada na luta de classes, o que enriquece a proposição acerca da discursividade. Não se propõe um reducionismo, tampouco a superposição desses dois campos teóricos; mas sim suas inter-relações e contribuições no que diz respeito ao real.

Nas bordas da língua, do sujeito e da história é o trajeto que será percorrido neste trabalho. "Borda", aqui, coloca-se enquanto essa "superfície" que se aproxima de um litoral - em que as margens são sempre impossíveis de serem delimitadas, que apontam para um movimento constante, e que mesmo se tratando de esferas que não se confundem (como o mar e a terra na imagem do litoral) fazem alguma espécie de fronteira, produzem uma zona de contato. Alude-se, ainda, à figura topológica do nó borromeano, em que o dentro e o fora estão em constante articulação, o verso e o reverso confundem-se e apresentam-se mutuamente. Isto é, uma figura que em meio às suas torções resulta em uma única face. Para escrever sobre o real, são referências como essas de bordas, litorais ou nó borromeano que permitem tocar na complexidade do objeto de estudo em questão.

\section{NAS BORDAS DA LÍNGUA...}

Considera-se importante começar trazendo a duplicidade do objeto da Linguística: "há língua e há línguas"(ORLANDI, 2004, p. 07). Tomar a língua em seu funcionamento, portanto em relação com a fala/enunciação/discurso, implica reconhecer a inscrição dos sujeitos na linguagem, em uma dimensão política, social, cultural, ideológica. E, por isso, sempre em movimento. 
Nesse sentido, Gadet e Pêcheux ([1981] 2004) colocam a língua como um complexo afetado pelo inconsciente e pela história. Eles trazem uma discussão sobre os limites e transgressões da língua, subvertendo a ideia de uma unicidade da língua, e trazendo o equívoco e a opacidade como inerentes, manifestados no ponto de entrecruzamento do impossível (linguístico) com a contradição (histórica), ou seja, no ponto em que a língua toca a história.

Coloca-se em xeque a concepção de língua como um sistema que possui um exterior no qual sujeitos ideais a põem em funcionamento, num processo comunicativo uniforme no qual sentidos seriam codificados e decodificados por emissores e receptores - como se a língua fosse um código que não possuísse história e como se ela não se constituísse juntamente com os falantes e a conjectura social e política. Ao contrapor-se com essas formulações, os estudiosos da $\mathrm{AD}$ propõem a língua como lugar de inscrição do sujeito e do discurso, produzindo sentidos. O discurso materializa-se na língua, inscreve-se nela, determinando o seu funcionamento: o discurso é produtor de real.

$\mathrm{O}$ trabalho dispendido pela $\mathrm{AD}$ aponta para a relação entre o linguístico, enquanto materialidade linguística, e o histórico, enquanto processo ininterrupto de produção de sentidos, que estabelece filiações e redes semânticas (PÊCHEUX, [1969] 1997; PÊCHEUX, [1988] 1995). Pêcheux afirma que a língua é a materialidade que dá as condições para os processos discursivos diferenciados e alerta para a necessidade de se distanciar da condição de evidência quando se trabalha com discursos. $O$ efeito de evidência e de unidade é sempre da ordem do imaginário. Daí a importância de se considerar que há um sistema, uma estrutura que singulariza a língua, mas que se faz necessário transpor essa lógica e pensar na língua em funcionamento, e não como uma abstração, concebendo aí o atravessamento do político e da ideologia, produzindo efeitos de sentido. São os fatores ideológicos que trazem esse efeito de evidência e de unidade anteriormente referidos, inclinando a uma determinada visada sobre as situações. $O$ político entra, aí, na medida em que engendra mecanismos de produções de sentidos, trazendo consigo a impressão de uma transparência da linguagem. Orlandi (1998) afirma que é necessário considerar a dimensão do político, indo além dos conteúdos e formulações, atentando para espessura semântica dos objetos simbólicos: "Esta espessura é função do político. Não há sentido que não tenha sido produzido em condições específicas, em uma relação com a exterioridade, com uma direção histórico-social que se produz em relações imaginárias que derivam de um trabalho simbólico" (ORLANDI, 1998, p. 75). É pelo funcionamento do político que se pode considerar a contradição e a abertura para outras leituras acerca do objeto sobre o qual aqui se reflete.

Morales (2003, p. 02) situa que "a língua comporta uma ordem (o real), que é condição para que o efeito de sentido entre locutores (a discursividade) dê-se como tal". A autora afirma que tal forma de conceber a língua rompe com o ideal da Linguística que tende a resistir a qualquer ruptura na linearidade do discurso (ambiguidades, lapsos, elipses). A perspectiva da AD considera a opacidade da língua, bem como trata o equívoco como um fato linguístico estrutural, o que a distingue de uma Linguística mais formal comentada anteriormente.

Baldini e Ribeiro (2016, p. 163) interrogam-se sobre "o que é a língua se a Psicanálise e o materialismo histórico existem?”. É a partir das reflexões de Pêcheux, Gadet, Milner (e outros linguistas), que chegam à conclusão deque é a partir da noção de 
real que tal questionamento pode ser desdobrado. Para eles, é inegável que a problematização do real como impossível específico à língua e à história traz uma certa virada $^{4}$ nas formulações de Pêcheux. O Real aparece, portanto, como elo de articulação entre a Linguística, a Psicanálise e o Materialismo Histórico.

A Psicanálise sublinha os tropeços da língua. São nesses intervalos, aberturas e brechas que se pode observar o advento do inconsciente. É nesse sentido que Mariani (2007) refere que o ato falho é um discurso bem-sucedido. É por essa via que se descortina algo do sujeito. Lacan preconiza que o inconsciente é estruturado como uma linguagem e enfatiza a primazia do significante. Em qualquer ponto do encadeamento significante podem ocorrer equívocos, falhas, deslizes, ambiguidades e deslizamentos, produzindo derivas do sentido, tanto para quem fala/escreve quanto quem escuta/lê (MARIANI, 2007).

A língua para a AD é “inatingível” (GADET; PÊCHEUX [1981] 2004). Há sempre pontos de resistência à univocidade lógica e às tentativas de dominação dos sentidos (MARIANI, 2007). Falar é escolher, escolher é renunciar. Assim, tudo não se pode dizer. Não há sentidos presos nas palavras - os sentidos só existem por meio de metáforas, na provisoriedade de alguma Formação Discursiva. As palavras significam na/pela história e na/pela língua. Nas produções metafóricas, há algo do mesmo e do diferente. Algo se preserva nos sentidos e algo novo se revela - marcas da historicidade e da ideologia na relação com a língua e com o discurso.

A língua é concebida, então, como paradoxalmente estruturada e furada - aí entram as possibilidades do simbólico nos processos de significação -, constituída por processos de paráfrases, polissemia, metáfora. $\mathrm{O}$ estrutural e o que é da ordem do não estabilizado na língua coexistem. Os deslizamentos de sentidos são sempre possíveis, já que a língua comporta os não-ditos, a incompletude, os furos constitutivos. Mariani (2007) enfatiza a metáfora como um acontecimento de língua, tomando esta como opaca, furada, suscetível ao equívoco e deslizamentos significantes.

Ferreira (1994, p. 09) posiciona-se por "uma língua na qual intervenha a sistematicidade e também a historicidade, e por aí o imaginário e a opacidade. Uma língua, enfim, que não seja translúcida, mas cuja espessura e densidade façam resistência". Para a autora, é fundamental operar com um conceito de língua que reconheça a sua multiplicidade do dizer e, ao mesmo tempo, que reconheça nos equívocos o real que lhe é próprio, que abriga um impossível no dizer e no formular.

Entre o possível e o impossível, entre o gramatical e o agramatical, entre o linguístico e o discursivo [...]. Com base na reflexão sobre os limites, sobre as fronteiras da língua e sobre o espaço das transgressões existente nela $[\ldots]$ o melhor caminho parece ser o de assumir as contradições e os deslocamentos, através do humor, do jogo de palavras, do chiste. (FERREIRA, 1994, p. 140)

O desafio de abordar o real da língua, considerando não só suas fendas e deslocamentos, mas também rompendo com noções de unidade, completude e

\footnotetext{
${ }^{4}$ Nas produções da Psicanálise, por sua vez, também se percebe uma virada no momento em que o real toma a cena das formulações de Lacan.
} 
transparência é sublinhado por Sousa (2016). A autora refere que "temos a urgência de tomar a língua em sua plástica equivocidade, marcada pela falta e pelo impossível que lhe são constitutivos, o que significa inferir tomá-la em sua condição de poesia" (SOUSA, 2016, p. 161).

Milner (1987), em "O amor da língua", traz que o real da língua mostra a irrupção do sem-sentido, do equívoco, da falha, como constitutivos do funcionamento do sujeito e do sentido. $\mathrm{O}$ autor refere-se ao equívoco próprio da língua como "o duplo sentido e o dizer em meias-palavras [...] uma locução, trabalhada pelo equívoco, é ao mesmo tempo ela mesma e uma outra" (MILNER, 1987, p. 13).

É pautado nisso que Pêcheux retoma a expressão lacaniana de que só há causa naquilo que falha (PÊCHEUX, [1988] 1995). Nessa mesma vertente de formulações, Mariani (2007) coloca que o Real "fura" a identidade da língua, denunciando a dimensão do non-sense. Não é possível tudo dizer, sempre há restos. Algo sempre rompe ou irrompe na cadeia significante Trata-se daquilo que "cai", que se desprende do significado - um "traço", um resto que remete ao que não é da ordem do significado, e sim do significante.

“O Real da língua reside naquilo que nela faz UM" (GADET; PÊCHEUX, [1981] 2004, p. 30). O “UM" é tomado aqui como algo sempre fugidio, inalcançável, impossível de se representar como um todo. E ainda: "A língua é afetada por uma divisão (figurada pela distinção entre o correto e o incorreto), que se sustenta pela existência de um impossível, inscrito na própria ordem da língua" (GADET; PÊCHEUX, [1981] 2004, p. 32). Gadet e Pêcheux vão além: colocam a língua como uma questão de Estado, no sentido do político que aí entra em jogo, por meio da luta de classes e relações de poder, produzindo assujeitamentos, anulação das diferenças, silenciamentos, apagamentos.

"O real da língua é o impossível” é o título da parte 5 do livro "A língua inatingível". Nesse pequeno e profundo espaço de formulações, Gadet e Pêcheux (2004) citam as ideias de Milner (1987) e mobilizam conceitos Lacanianos importantes: a noção de "lalangue" (em português: "alíngua") e a afirmação de que "não há relação sexual", articulando-as ao que concebe enquanto o real da língua. $\mathrm{O}$ que Lacan propõe com o conceito de lalangue é que há uma apropriação e um uso muito singulares na relação do sujeito com a língua, em que os equívocos e as possíveis desarticulações da língua fazemse presentes. No Seminário 20 - "Mais, ainda”, ele nos diz:

a linguagem, sem dúvida, é feita de alíngua. É uma elucubração de saber sobre alíngua. Mas o inconsciente é um saber, um saber-fazer com alíngua. E o que se sabe fazer com alíngua ultrapassa em muito o de que podemos dar conta a título de linguagem. Alíngua nos afeta primeiro por tudo que ela comporta como efeitos que são afetos. Se se pode dizer que o inconsciente é estruturado como uma linguagem, é no que os efeitos de alíngua, que já estão lá como saber, vão bem além de tudo o que o ser que fala é suscetível de enunciar. (LACAN, [1985] 2008, p. 190; grifo nossos).

A elaboração do conceito de lalangue contribui para marcar a impossibilidade da completude da língua, sendo ela sempre não-Toda (MILNER, 1987). Lacan e Milner debruçaram-se sobre a lalangue em suas produções teóricas. A este neologismo, Lacan ([1966] 1998) associa a lalação do bebê. Trata-se de uma "língua" que se produz a partir 
da função materna, transmitida ao sujeito em tempos primordiais de sua constituição. Remete a um modo particularizado e desestruturado de cada sujeito habitar a língua, algo que faz furo ao social e que se apresenta como o mais próprio de cada um, portanto, sujeito a todos os desvios. Ela remete ao real, na medida em que a palavra está fora do campo da significação e encontra-se em um fluxo polifônico, um traço apagado/rasurado de laços muito iniciais do sujeito com o outro materno. Milner (1987, p. 15) traz que da lalangue só se tem como ter notícias via semblante e que ela "é, em toda língua, o registro que a consagra ao equívoco". Ele retoma Lacan, em sua afirmação de que a verdade é sempre não-toda. Faltam sempre palavras, portanto a verdade e a lalangue ${ }^{5}$ atingem o real, são da ordem do impossível, do irrepresentável. "A língua suporta o real da alíngua" (MILNER, 1987, p. 19). O autor coloca que em nome de um positivismo científico, que busca regularidades universais, a gramática e a Linguística recusam-se a aceitar o que de real insiste nas línguas: o lugar do equívoco.

O real foi um conceito construído por Lacan ao longo de seu ensino, sofrendo reformulações e avanços. Importa aqui destacar o quanto está atrelado ao que resiste à simbolização, ao que faz furo no simbólico, ao que escapa ao sentido, ao impensável, ao impossível. Aponta para uma "exterioridade íntima" do sujeito. O real "ex-siste", pontua Lacan no Seminário R.S.I. (1974-1975). O Real só tem ex-sistência se encontra no simbólico e no imaginário a parada, algum ponto possível de articulação. Êxtimo é um neologismo criado por Lacan para indicar algo paradoxal: aquilo que é familiar ao sujeito, que remete ao seu íntimo e a sua singularidade, está no exterior, está fora ${ }^{6}$. Lacan retoma essa ideia para falar do ponto vazio da estrutura, posição por excelência do objeto a (objeto causa do desejo, objeto da falta).

"O real, justamente, é o que não anda, é uma pedra no meio do caminho, bem mais, é o que não cessa de se repetir para entravar essa marcha” (LACAN, 1974, s.p.). Lacan situa o real, portanto, como uma fratura constitutiva que funciona tal qual a angústia: um afeto que não engana, posto que sinaliza a proximidade com o objeto do desejo e, portanto com a falta. O real é o que faz furo no simbólico, rasgando com o que é da ordem da imagem ou da representação. Assim, Lacan relaciona o registro do Real com o gozo, ou seja, com aquilo que está incidindo na compulsão à repetição, efeito da operação psíquica da pulsão de morte. Algo que remete a um excesso, não interditado, um absoluto, sempre impossível, mas ao qual o sujeito se insere numa busca incessante.

Diante de tais considerações, concebe-se que o analista, em sua prática psicanalítica, vai escutar o sujeito do desejo, que comparece pontual e efemeramente entre intervalos de significantes, cujo discurso carrega metáforas, metonímias, condensações, deslocamentos, recalcamentos, etc., atentando para o que irrompe enquanto real. Já o analista de discurso vai trabalhar com o logicamente estabilizado e desestabilizado e com as tensões entre o dito e o não-dito, compreendendo os processos envolvidos nos deslizes e pontos de deriva da língua, que produzem algum sentido no corpus analisado (que pode

\footnotetext{
5 Ainda sobre a lalangue, Lacan refere: “não é por acaso que n'alíngua, qualquer que seja ela, na qual alguém recebeu uma primeira marca, uma palavra é equívoca. [...] É absolutamente certo que é pelo modo como alíngua foi falada e também ouvida por tal ou qual em sua particularidade, que alguma coisa em seguida reaparecerá nos sonhos, em todo tipo de tropeços, em toda espécie de modos de dizer" (LACAN, [1975] 1998, p. 7). A questão, para Lacan, é o saber-fazer com alíngua, algo que os poetas conseguem bem. ${ }^{6}$ Esse conceito tem relação com o Unheimlich, o estranho familiar, que Freud usa em seu texto "O estranho" (1919). Vincula-se, também, ao conceito de das Ding ("Coisa"), termo alemão utilizado por Freud já no início de seus escritos e que será retomado na leitura lacaniana.
} 
sempre ser outro, ainda que não qualquer um), considerando em sua análise o estatuto do real da língua.

O conceito de Real permite, no que diz respeito à língua, apontar para a sua opacidade, sua não-completude, para a impossibilidade de tudo dizer. Ainda, para a noção de língua não como uma representação, fechada, comportando sentidos prontos ou prévios, mas a língua em movimento, com suas porosidades, furos, falhas, que não cessam de não se inscrever. A escrita da língua mostra-se como uma tentativa de fazer alguma borda a esse inominável para sempre inatingível.

\section{NAS BORDAS DO SUJEITO...}

O real do sujeito vincula-se ao seu duplo assujeitamento e ao seu caráter de divisão, de sujeito barrado. O sujeito discursivo é este que, conforme Pêcheux ([1969] 1997; [1983] 2012), é interpelado pela ideologia e dotado de inconsciente. Trata-se do sujeito dividido, que é efeito de linguagem. Nesse viés, ainda que não se confundam, inconsciente e ideologia encontram-se materialmente ligados na ordem significante da língua (MARIANI, 2007). O assujeitamento à linguagem relaciona-se diretamente com o plano ideológico, com as identificações do sujeito às Formações Discursivas muitas vezes inacessíveis à consciência. A partir dos fatores históricos e ideológicos produz-se o efeitosujeito.

Pêcheux ([1969] 1997) reconheceu a heterogeneidade e o assujeitamento como constitutivos do discurso. Isto é, o sujeito pode assumir diferentes posições no discurso, sendo o discurso produto dessa heterogeneidade. O que se apresenta, portanto, é um sujeito dividido que se materializa nas tomadas de posição frente aos saberes que estão inscritos nas Formações Discursivas que o constitui. É do encontro entre sujeito, história e língua que se torna possível a tomada de posição de um sujeito interpelado pela ideologia e atravessado pelo inconsciente. É daí que o analista de discurso pode identificar diferentes posições-sujeito, tal como se inscrevem no todo complexo com dominante (interdiscurso), no qual as formações ideológicas correspondem ao domínio de uma dada Formação Discursiva, regionalizando saberes.

Indursky (2008) propõe uma revisão da trajetória da noção de sujeito, em diferentes momentos teóricos do desenvolvimento do que chamou Teoria da Análise do Discurso, em especial nas formulações e reformulações de Michel Pêcheux no percurso de suas obras. Passando pela ideia do sujeito como um lugar determinado na estrutura social, para uma teoria da subjetividade psicanalítica e, posteriormente, para uma teoria não-subjetiva da subjetividade. A articulação entre ideologia e inconsciente para se pensar a subjetividade é destacada pela autora, ao referir-se ao "teatro da consciência" referido por Pêcheux: "o indivíduo, ao ser interpelado pela ideologia, constitui-se em sujeito e, com isso, cria as condições necessárias para a produção de sentido e seus efeitos de evidência" (INDURSKY, 2008, p. 32).

A ilusão de liberdade, constitutiva do sujeito como origem, diz do laço sujeitohistória, produto da ideologia (ORLANDI, 2017). Orlandi, ao problematizar o conceito de Forma-sujeito-histórica, refere que o sujeito é dividido em si e entre si, efeito da incidência do ideológico e das formações do inconsciente. 
Há um certo efeito de evidência e de naturalização dos sentidos produzido pela ideologia que comumente aparece nos discursos dos sujeitos - conforme as posições sociais que ocupam -, como se houvesse um dizer já dado, um sentido que lhe aparece como evidente, natural de se enunciar desde aquele lugar. Esse processo de suposta transparência dos sentidos provoca no sujeito a ilusão de centralidade e de originalidade enquanto formulador de enunciados. Aqui o político apresenta-se enquanto fator determinante no jogo de posições-sujeito inscritas em Formações Discursivas imbricadas em Formações Ideológicas. Por isso não se concebe um sentido unívoco, e sim efeitos de sentido, redes complexas de sentido nas quais o novo e o mesmo se entrelaçam e se resignificam mutuamente:

Em nossa concepção, há, sem dúvida, posições que o sujeito assume ao manifestar-se, representando uma posição determinada ideologicamente. Por isso, essa "liberdade" do sujeito que é individualizado pelo Estado não passa de um efeito imaginário produzido pela ideologia. Há uma intrincação entre discurso e ideologia que legitima a condição do sujeito enquanto descentrado, lacunar, disperso, múltiplo, o que reafirma a caracterização material do discurso e do sentido, tendo em vista que a unidade do sujeito é da ordem do imaginário. (PETRI, 2004, p. 53)

A AD aproxima-se da Psicanálise trazendo elementos da teoria de Lacan para conceituar o real do sujeito. Lacan considera que o inconsciente é estruturado como uma linguagem e que seus efeitos se manifestam no terreno da língua. As formações do inconsciente - lapsos, atos falhos, chistes, sonhos - estabelecidas por Freud - revelam-se indissociáveis da linguagem, e precisam ser buscadas no campo das palavras, no sujeito que as enuncia. Para Lacan, o sujeito somente existe enquanto efeito de linguagem, por referência à cadeia de significantes: O sujeito não é jamais senão pontual e evanescente, pois ele só é sujeito por um significante e para outro significante (LACAN, [1966]1998). É quando a língua tropeça na fala de um indivíduo, quando ao invés de falar o falante é falado por sua língua, que ele se torna ser de linguagem. Esse caráter de alteridade e de estranheza que a língua e a linguagem têm para o próprio falante; a maneira como ela escapa à sua vontade, subverte e "trai" as intenções daquele que fala.

O real do sujeito remete ao seu saber insabido, que não se transmite, mas que existe e produz efeitos - trata-se da verdade do inconsciente, que não cessa de não se inscrever (LACAN, [1985]2008). É nesse contexto que Lacan formula os conceitos de gozo, lalangue e sinthoma, articulados ao registro do real.

$\mathrm{O}$ dizer e o dito não são da mesma ordem. $\mathrm{O}$ dito não recobre o dizer. $\mathrm{O}$ dizer, portanto, relaciona-se a essa dimensão do real do sujeito. O saber não sabido é testemunhado pelas formações do inconsciente, ele escapa ao ser falante, rompe com qualquer pretensão de domínio.

A afirmação de Lacan ([1985] 2008) de que não há relação sexual também tangencia o real, já que o que se preconiza aí é a incompletude constitutiva das relações, a impossibilidade de complementariedade, a falta estruturante do sujeito. Lacan formula o conceito de Real numa perspectiva topológica. Tomando da Matemática noções de topologia, ele apresenta o nó borromeano, mostrando o imbricamento e o jogo recíproco 
entre R-S-I ${ }^{7}$ (Real-Simbólico-Imaginário). Conforme Lacan, o real só se poderia inscrever por um impasse na formalização, tal qual ocorre nas matemáticas: $\mathrm{O}$ real é o mistério do corpo falante, é o mistério do inconsciente" (LACAN, [1973] 2008, p. 140).

Vorcaro e Capanema (2016) esclarecem que, ao propor essas três dimensões psíquicas implicadas no sujeito falante, Lacan faz uso desse nó, dotando de valores equivalentes os três registros, ao mesmo tempo demarcando suas distinções: "cada um deles se relaciona com os outros dois em um modo de alteridade em que nenhum deles se liga exclusivamente ao outro, sempre havendo um terceiro que lhes faz mediação" (VORCARO; CAPANEMA, 2016, p. 13). As psicanalistas referem, ainda:

portanto, o sujeito está triplamente determinado por três cordas: cada uma tem seu furo, sua consistência e sua "ex-sistência", ou seja, há consistência em R, S, I; há buraco em R, S, I, e há "ex-sistência", em $\mathrm{R}, \mathrm{S}, \mathrm{I}$. A heterogeneidade que se mantém, especificando cada registro, pode ser constatada nos outros dois, demonstrando uma modalidade particular de atamento entre os três que, por isso, fazem Um. (VORCARO; CAPANEMA, 2016, p. 13)

As autoras advertem para o fato de que o nó borromeano de três elos perfeitamente trançados não existe, estando apenas situado enquanto "modelo", "ideal". Faz-se necessário relativizar essa amarração, já que "[...] em cada sujeito, o(s) sintoma(s) explicita(m) que ele se constituirá, desde sempre, falhado, comportando necessariamente os lapsos dos nós" (VORCARO; CAPANEMA, 2016, p. 15).

A Análise de Discurso compartilha desses conceitos, mas os joga para a dimensão discursiva. Noções como "efeito de evidência" e "Formações Imaginárias" ilustram a concepção de que o ideal, a completude, o todo, só se alcançam imaginariamente, miticamente. Petri (2004) refaz um percurso dessas três noções e do modo como esses conceitos são mobilizados pela $\mathrm{AD}$, colocando o real do discurso como lugar de dispersão e de incompletude, em que sujeito e sentido se constituem: "No real é possível observar a dispersão, a imperfeição, a falta, a não-linearidade, a descontinuidade, a incompletude e o contraditório que constituem sujeito e sentido, no discurso" (PETRI, 2004, p. 122). Ela afirma, ainda, que é quando o analista está trabalhando com materialidades discursivas que o conceito de real precisa ser fortemente considerado, pois é onde se percebe movimentar o real da língua e da história.

No livro "Materialidades discursivas", Courtine e Marandin ([1981] 2016, p. 33) lançam a pergunta "Que objeto para análise de discurso?" e afirmam que o sujeito, em $\mathrm{AD}$, ao tomar a palavra, entra numa via de repetição a qual ele ignora ser o já-dito. Assim, o sujeito é "ou uma máscara (um lugar vazio) na qual um indivíduo indefinido molda sua voz, uma voz impessoal em que as regras da sintaxe e os olhos da significância operam sobre um puro conteúdo, ou um 'locutor coletivo', o que reduz a realidade social dos discursos à existência de aparelhos homogêneos, sujeitos plenos de seu discurso" (COURTINE; MARANDIN, [1981] 2016, p. 45).

\footnotetext{
${ }^{7} \mathrm{O}$ simbólico relaciona-se à linguagem, às possibilidades de recobrimento via palavras, àquilo que nomeia e que faz uma mediação entre as palavras e as coisas. O registro do Imaginário remete ao que é especular, representacional, produz uma "impressão" da realidade e o Real, como já mencionado, denuncia a falta estruturante, escapa à apreensão e simbolização.
} 
O sujeito é dividido, faltante, não-todo, interpelado ideologicamente, traído pelas fendas de seu inconsciente e atravessado pela exterioridade que o constitui. $\mathrm{O}$ real do sujeito remete, portanto, à sua condição de assujeitamento, o que rompe com as ilusões de domínio de seu dizer e dos sentidos que produz, abrindo espaço sempre para os deslizamentos significantes.

É nessa perda, nessa falta, nesse furo, nesse intervalo que o sujeito advém. Há, portanto, uma falta que marca o sujeito simbolicamente inscrito, imaginariamente constituído e ideologicamente interpelado. Nas palavras de Melo (2005),

definir o sujeito como desejante, implica em aceitar a impossibilidade de simetrização, dada a ingerência do real como impossibilidade, isto é, como o que causa a fenda no simbólico, que provoca deslocamentos no tangente à língua, à enunciação, à historicidade, cujo impacto no entendimento da noção de sentido em análise de discurso é nuclear. (MELO, 2005, p. 67-68)

Contudo, cabe considerar as discrepâncias importantes entre a ideia de sujeito do desejo Lacaniano e da "forma-sujeito-histórica" da AD: enquanto para a Psicanálise a dimensão pulsional é fortemente destacada, na $\mathrm{AD}$ o sujeito jurídico, assujeitado pelos Aparelhos Ideológicos do Estado ganha destaque. Frente a isso, considera-se importante a não confusão entre os campos, porém se aposta na potência do entremeio entre esses saberes para enriquecer a noção de sujeito discursivo.

\section{NAS BORDAS DA HISTÓRIA...}

Na perspectiva da Análise de Discurso, a história tem relação direta com o sentido e não se associa com evolução ou cronologia. "A História está na Língua. Esta é uma inscrição incontornável [...]. Não se pode ficar alheio a tal assertiva, sob pena de nos afastarmos do que toca mais de perto os domínios do discurso" (FERREIRA, 1994, p. $17)$.

Na introdução do livro "A língua inatingível”, Orlandi (2004, p. 07) refere que "o intangível, o ausente e o evidente são modos de presença muito diversos de processos inconfundíveis que tocam a relação da língua com a história. Morales (2003, p. 03) enfatiza que há, na ordem da história, o lugar do equívoco e que isso "impede o sucesso total das identificações e obriga o sujeito a tomar uma posição, a interpretar". A autora elucida as diferenças nas concepções de Milner (1987), Pêcheux e Gadet ([1981], 2004) acerca desse tema, na medida em que Milner considera a história como um simples efeito imaginário, não o situando enquanto real contraditório. Já para Pêcheux e Gadet a contradição é fundante no encontro do sujeito com o que é da ordem da história, tendo em vista que a língua é tomada enquanto política.

$\mathrm{Na}$ mesa-redonda "discurso história-língua", do livro "Materialidades Discursivas", Pêcheux ([1981] 2016, p. 287) lança a questão: "Há uma necessidade, numa análise materialista do real dos processos históricos, de ser cego em relação às modalidades materiais de existência dos discursos?”. Pêcheux ([1983] 2012) situa que, para além do real da língua, há também o real da história que se vincula ao impossível e 
às contradições sempre presentes na apreensão das historicidades ${ }^{8}$. Nesse gesto de interpretação, ele evita uma leitura e análise a-histórica e biologizante dos sujeitos. Se não se pode apreender o real da língua, também não é possível apreender a história. A história, como disciplina, é tomada por Gadet e Pêcheux ([1981] 2004) como uma sucessão de desvios e escorregadelas, de mudanças de olhares sobre os fatos, através de jogos de palavras, deslizamentos de sentido, que refletem mudanças sociais e carregam as marcas da ideologia.

O real da história está na dimensão do inenarrável. Versões e silenciamentos operam aí e significam. $\mathrm{O}$ apagamento de imagens indesejadas da memória coletiva, de dados biográficos, a reescritura de histórias, a remontagem dos fatos segundo o que seria mais conveniente, são situações que lançam luz a esse real da história.

Ao articular silêncio e metáfora, Mariani (2007, p. 15) situa que o silêncio torna possível compreender a fluidez dos sentidos, além da relação entre história, memória e os apagamentos aí produzidos: "Os sentidos existem nas relações de metáfora". Trata-se de um silêncio enquanto fator essencial que está na condição do significar. E ressalta-se que esse não-dizer vincula-se à história e à ideologia.

Os fatos reclamam sentidos. A historicidade é a interpretação que opera a partir do momento em que a língua e a história se trespassam, constituindo "a forma material (não abstrata como a da Linguística) que é a forma encarnada na história para produzir sentidos" (ORLANDI, 2009, p. 19). Gadet e Pêcheux ([1981] 2004, p. 52) situam o real da história "como uma contradição da qual o impossível não seria foracluído". Os autores propõem não só que os efeitos do materialismo histórico vêm mostrar como os aparelhos ideológicos do Estado constituem o sujeito, mas também que efeitos produzem. Mais adiante, sintetizam o ponto em que a língua atinge a história:

o equívoco aparece exatamente como o ponto em que o impossível (linguístico) vem aliar-se à contradição (histórica) [...]. A irrupção do equívoco afeta o real da história, o que se manifesta pelo fato de que todo o processo revolucionário atinge também o espaço da língua. (GADET; PÊCHEUX, [1981] 2004, p. 64)

As derivas do sentido ganham destaque nessa concepção. O sentido é sempre disperso, assim como também o é o sujeito, descontínuo, dividido, contraditório, opaco. A história passa a ser tomada aqui não como uma verdade, absoluta, linear, e sim suscetível de falhas, faltas. História e ficção se aproximam. A ficção, para Lacan, tem estrutura de verdade. Ou seja, trata-se de uma verdade sempre particularizada, não generalizável. Posto que passa pela linguagem, torna-se impossível acessar a verdade. Ela é sempre não-toda, uma semi-verdade. O retorno dessa verdade não cessa de não se escrever, o que sustenta o trocadilho entre ficção e fixão (LACAN, 1973). Para Lacan,

tudo o que há por dizer da verdade, da única, ou seja, que não existe metalinguagem (afirmação feita para situar todo o lógico-positivismo) que nenhuma linguagem pode dizer o verdadeiro sobre o verdadeiro, uma vez que a verdade se funda pelo fato de que fala, e não dispõe de outro meio para fazê-lo. (LACAN, [1966] 1998, p. 882)

\footnotetext{
${ }^{8}$ No que tange à história, nota-se então a importante contribuição de Pêcheux ao formular que há um real da história, o que não foi considerado por Milner e não foi trabalhado por Lacan.
} 
Isso sustenta a afirmação de que o inconsciente é estruturado como linguagem, e que o encontro com a "verdade" (do sujeito do inconsciente ou, deslocando para a questão aqui proposta, a verdade da história) é sempre um encontro faltoso ${ }^{9}$. Assim, compreendese que um acontecimento histórico clama/reclama por discursivização para existir como tal e obter o estatuto de acontecimento discursivo ${ }^{10}$. Não há uma "colagem" da memória nos objetos históricos. Como refere Baldini e Ribeiro (2016, p. 177): "considerar a existência de um real da história é fazer uma aposta política sobre o funcionamento da contradição a partir de uma tomada de posição materialista". Trata-se da inscrição da língua (passível de falhas) na história, o que produz equívoco. Este se dá, portanto, no funcionamento da ideologia e/ou do inconsciente. O equívoco é a falha da língua na história. É a partir da discussão sobre o valor do equívoco que Ferreira (1994, p. 19) afirma que é pelo equívoco "que a língua (ou melhor, a lalangue e o impossível contido nela) encontrará a história (a contradição) [...]".

Assim, o que se faz possível acessar no que diz respeito à história são versões, interpretações, marcadas pela falta, pelo equívoco, por efeitos metafóricos, ou seja, decorrentes do trabalho do sujeito (ORLANDI, 2009). Assim, a AD está irremediavelmente perpassada pelo entremeio do real da língua e do real da história.

\section{CONSIDERAÇÕES FINAIS}

Interrogar-se sobre a existência de um Real próprio às disciplinas de interpretação exige que o não-logicamente-estável não seja considerado a priori como um defeito, um simples furo no Real. É supor que entendendo-se o "real" em vários sentidos - possa existir um outro tipo de real, e também um outro tipo de saber, que não se reduz à ordem das "coisas-a-saber" [...] Logo um real constitutivamente estranho à univocidade lógica e um saber que não se transmite, não se aprende, não se ensina, e que, no entanto, existe produzindo efeitos. (PÊCHEUX, [1983] 2012, p. 43)

Com essa afirmação de Pêcheux, é retomada a necessidade de trabalhar com a noção de "bordas" para falar do que é da ordem do inominável. Trata-se de "bordear" porque é somente o que se faz possível nesse terreno, dada a complexidade do tema e os alcances teóricos que ele abrange. Pensar a interlocução da Psicanálise com a Análise de Discurso em suas formulações sobre o que tange ao real possibilitou a compreensão acerca daquilo que é, talvez, a dimensão mais nuclear com a qual um analista ou um analista de discurso se depara. Nesse sentido, concorda-se com a colocação de Sousa (2016, p. 157) de que a língua não dá conta de abrigar e/ou conter a "coisa", podendo apenas contorná-la: "assim, o verbo falta impedido de dar conta do buraco que não

\footnotetext{
9 Lacan trabalha com o conceito de "semblante", vinculado a essa discussão. Tal discussão pode ser encontrada no seminário "De um discurso que não fosse do semblante” (LACAN, 2009[1971]).

${ }^{10}$ Para Pêcheux, o acontecimento discursivo é aquilo que desestabiliza e produz certa ruptura em um sistema de regulação anteriormente "estável", que por consequência produz deriva de sentidos. Rompe-se assim com a ordem da repetibilidade, mexe-se com a memória, e produz-se uma nova ordem, uma nova reorganização da memória e sentidos outros são agregados. Para Pêcheux, um acontecimento "é um ponto de encontro entre uma atualidade e uma memória" (PÊCHEUX, [1983] 2012, p.17).
} 
consegue tamponar, tendo somente o percurso de dar mais uma volta a mais - e mais outra e sempre alguma a mais - em torno dele" (SOUSA, 2016, p. 157).

Certamente faz-se necessário considerar as especificidades e particularidades de cada campo do saber aqui abordado. Ainda que se tenha a cautela de preservar as diferenças de posicionamentos, frente a este estudo foi possível reconhecer a via de mão dupla em que a $\mathrm{AD}$ e a Psicanálise transitam e apresentam contribuições.

A apreensão do real é sempre faltosa. Em sua relação com o real, sujeitos, sentidos e história são constitutivamente dispersos, sujeitos a derivas. Sempre há o furo, a brecha, a descontinuidade, o vazio, o equívoco. E é justamente aí, nessa brecha, nesse espaço do "entre", nesses intervalos, que se constituem os sujeitos, os discursos e a história. A língua está para o impossível/inatingível assim como o sujeito está para a falta, para a nãocomplementariedade, para o seu vazio constitutivo em sua relação com o objeto para sempre perdido. A história engendra-se, aí, enquanto uma "verdade" não-toda, uma ficção com estrutura de "verdade", sempre atravessada pelos fatores políticos e ideológicos.

Assim configura-se o esforço aqui empreendido em compreender um pouco mais sobre a dimensão do real implicado na língua, no sujeito e na história. Em relação ao real, não se faz possível o descobrir (ou "des"-“cobrir"), e sim se depara/se encontra com ele, se é invadido pelos rumores de seus efeitos. Romper com essa perspectiva de uma "saturação", de uma "universalidade", de uma "origem" é estar disposto a ler e a compreender as questões a partir de uma perspectiva que vai além da evidência (a desconstruir), da realidade e da historicidade.

\section{REFERÊNCIAS}

BALDINI, L.; RIBEIRO, T. O que é a língua se a psicanálise e o materialismo histórico existem? Línguas e Instrumentos Linguítiscos, nº 38, 161-187, jul-dez 2016.

COURTINE, J.; MARANDIN, J. Que objeto para a análise de discurso? Em: CONEIN, C.; COURTINE, J.; GADET, F.; MARANDIN, J.; PECHEUX, M. (Orgs.). Materialidades Discursivas. Campinas: Editora Unicamp, [1981] 2016. p. 33-54.

FERREIRA, M.C.L. A resistência da língua nos limites da sintaxe e do discurso: da ambiguidade ao equívoco. Tese. Doutorado em Linguística, Instituto de Estudos da Linguagem, Universidade Estadual de Campinas, Campinas, 1994.

GADET, F.; PÊCHEUX, M. A língua inatingível: o discurso na história da linguística. Campinas: Pontes, [1981] 2004.

INDURSKY, F. Unicidade, desdobramento, fragmentação: a trajetória da noção de sujeito em Análise do Discurso. Em: MITTMANN, S.; GRIGOLETTO, E.; CAZARIN, E. (Orgs.). Práticas Discursivas e identitárias. Sujeito \& Língua. Porto Alegre, Nova Prova, PPG-Letras/UFRGS, 2008. (Col. Ensaios, 22, p. 09-33) 
LACAN, J. O Seminário, livro 20: mais, ainda. Trad. Bras. Rio de Janeiro: Jorge Zahar, [1985] 2008.

Conferência em Genebra sobre o Sintoma. OPÇÃO LACANIANA. São Paulo, Eólia, n. 23, 6-16, [1975] 1998.

A terceira. Cadernos de Lacan, Porto Alegre, APPOA, v. 2, [1974] 2002.

Escritos. Rio de Janeiro: J. Zahar, [1966] 1998.

O Seminário, livro 22: R.S. I. (Seminário inédito, não publicado). Disponível em: http://lacanempdf.blogspot.com.br/2017/03/o-seminario-22-rsi-jacqueslacan.html; acesso em 10 mar. 2018.

MARIANI, B. Silêncio e metáfora, algo a se pensar. REVISTA TRAMA, v. 3, n. 5, 55$71,1^{\circ}$ Semestre de 2007.

MELO, M.F.V. Psicanálise e análise de discurso: interlocuções possíveis e necessárias. Latin-American Journal of Fundamental Psychopathology [on-line], v. 1, 61-71, 2005.

MILNER, J. C. O amor da língua. Porto Alegre: Artes Médicas, 1987.

MORALES, B. O real da língua e o real da história: considerações a partir do texto La lengua de nunca acabar. Anais do I SEAD (Seminário de Estudos em Análise do Discurso), Porto Alegre, RS, UFRGS, 2003. Disponível em http://www.ufrgs.br/analisedodiscurso/anaisdosead/sead1_paineis.html; acesso em 10 mar. 2018.

ORLANDI, E. P. Eu, Tu, Ele - Discurso e Real da História. Campinas: Pontes Editora, 2017.

Análise de Discurso: princípios e procedimentos. $8^{\text {a }}$. ed. Campinas: Pontes, 2009.

. Discurso e argumentação: um observatório do político. Fórum Linguístico, Florianópolis, n. 1, 73-81, jul./dez, 1998.

. Sobre o intangível, o ausente e o evidente. Em: GADET, F.; PÊCHEUX, M. A língua inatingível: o discurso na história da linguística. Campinas: Pontes, [1981] 2004. p. 7-10.

PÊCHEUX, M. O discurso: estrutura ou acontecimento. Trad. Bras. $6^{\text {a }}$. ed. Campinas: Pontes, [1983] 2012.

Semântica e discurso: uma crítica à afirmação do óbvio. Trad. Bras. Campinas: $\overline{\text { Editora }}$ da Unicamp, [1988] 1995. 
Análise automática do discurso (AAD - 69). Em: GADET, F.; TAK, T. (Orgs.).

Por uma análise automática do discurso. Uma introdução à obra de Michel Pêcheux. Campinas: Ed. da Unicamp, [1969] 1997. p. 61-105.

Mesa-redonda: discurso, história, língua. Em: CONEIN, C.; COURTINE, J.; GADET, F.; MARANDIN, J.; PÊCHEUX, M. Materialidades Discursivas. Campinas: Ed. da Unicamp, [1981] 2016. p. 283-319.

PETRI, V. Imaginário sobre o gaúcho no discurso literário: da representação do mito em Contos Gauchescos, de João Simões Lopes Neto, à desmitificação em Porteira Fechada, de Cyro Martins. Tese. Doutorado em Letras, Universidade Federal do Rio Grande do Sul (UFRGS), Porto Alegre, 2004.

SOUSA, L.M.A. O real e a poesia nos entremeios litorâneos de Pêcheux e Lacan. Fragmentum, Santa Maria, Programa de Pós-Graduação em Letras, UFSM, n. 47, 155 167, Jan./Jun. 2016.

VORCARO, A.; CAPANEMA, C. Uma introdução ao nó borromeano. (In)Formação, Boletim da Clínica de Estudos e Intervenções em Psicologia, Universidade Federal de Santa Maria, Santa Maria - RS, n. 10, 13-16, 2016.

Artigo recebido em: novembro de 2017.

Aprovado e revisado em: fevereiro de 2018.

Publicado em: maio de 2018.

\section{Para citar este texto:}

JORDÃO, Aline Bedin; PETRI, Verli. No entremeio da Análise de Discurso e da Psicanálise: as bordas do real. Entremeios [Revista de Estudos do Discurso, ISSN 21793514, on-line, www.entremeios.inf.br], Seção Estudos, Programa de Pós-Graduação em Ciências da Linguagem (PPGCL), Universidade do Vale do Sapucaí (UNIVÁS), Pouso Alegre (MG), vol. 16, p. 133-147, jan. - jun. 2018.

DOI: http://dx.doi.org/10.20337/ISSN2179-3514revistaENTREMEIOSvol16pagina133a147 